\title{
Queensferry Crossing, UK: project scope and development history
}

\author{
Lawrence Shackman BSc, CEng, FICE, FCIHT \\ Project Manager, Transport Scotland, Rosyth, UK (corresponding author: \\ lawrence.shackman@transport.gov.scot) \\ Mike Glover OBE, FREng, FIStrE \\ Arup Fellow, Arup, London, UK
}

lain Murray BSc, CEng, FICE, MCIHT

Operations Director, Jacobs, Glasgow, UK

Stuart Hunter CEng, MICE

Director, Arup, New York, USA

The Forth Road Bridge has carried road traffic across the Forth estuary in Scotland, UK, since 1964. It was replaced in September 2017 by the Queensferry Crossing, the country's biggest infrastructure project in a generation. The outturn $£ 1.34$ billion replacement crossing project consists of a $2.7 \mathrm{~km}$ long cable-stayed bridge, associated connecting roads and junction improvements and a state-of-the art $22 \mathrm{~km}$ long intelligent transport system to manage traffic through the project corridor. This paper describes the project history, its development and scope.

\section{Introduction}

The Queensferry Crossing in Scotland, UK, was formally opened to traffic by Her Majesty Queen Elizabeth II on Monday 4 September 2017 as the replacement crossing to the Forth Road Bridge, exactly 53 years to the day from when she opened it in 1964. The Forth Road Bridge has successfully carried road traffic across the Forth estuary during that time. However, the deteriorating condition of the bridge, particularly in relation to the main suspension cables, and the great difficulty in rehabilitation without massive disruption to traffic, resulted in the commissioning in December 2007 of a replacement crossing to secure the future of cross-Forth travel. The wisdom of this decision was further highlighted by the full closure of the Forth Road Bridge for 3 weeks in December 2015 due to the failure of one of its truss end-links.

The replacement crossing has been Scotland's biggest infrastructure project in a generation. It consists of a $2.7 \mathrm{~km}$ long cable-stayed bridge, associated connecting roads and junction improvements and a state-of-the-art $22 \mathrm{~km}$ long intelligent transport system (ITS) to manage traffic through the project corridor, similar to those installed on the M42 and M25 motorways. All of these elements are key to maintaining the strategically vital link across the estuary.

The outturn cost of the project was $£ 1.34$ billion substantially lower than the initial estimates for the project of $£ 3 \cdot 2-4 \cdot 2$ billion - and was opened only 10 weeks after the contracted date agreed in 2011.

This paper describes the various stages of the project, from initial scoping through to opening of the crossing.

\section{The Forth Road Bridge}

The Firth of Forth separates the Scottish capital of Edinburgh from the Fife Council area to the north. The lowest crossings of the Forth at Queensferry, approximately $12 \mathrm{~km}$ west of Edinburgh, are a pair of historic grade A listed bridges - the Forth Road Bridge, Britain's first long-span suspension crossing, which was opened in September 1964 (Anderson et al., 1965), and the famous Forth Bridge cantilever rail crossing, completed in 1890 (Mackay, 1993) and now a World Heritage Site.

The Forth Road Bridge has a main span of $1006 \mathrm{~m}$ and at the start of its life it carried around 4 million vehicles per year. It now carries around 24 million vehicles per year and provides a vital link between Fife, Edinburgh and the east coast of Scotland.

Until June 2015, the Forth Road Bridge was maintained and operated by the Forth Estuary Transport Authority (Feta). The condition of the bridge has gradually deteriorated throughout its lifetime, primarily because of the increased levels of traffic with substantially higher heavy goods vehicle (HGV) axle weights and the effects of weather. The most serious problem concerns the main suspension cables (Colford, 2008, 2011).

In 2004, Feta undertook an inspection of the main suspension cables, which followed US guidelines as no others existed. This survey identified a significant number of broken and corroded wires and led to an estimate that the cables had lost around $10 \%$ of their strength. Extrapolating forward, this deterioration gave predictions that indicated restricting HGVs from using the bridge could be required by 2014, with complete closure by 2017. A further cable inspection in 2008 indicated that the cables may be deteriorating at a slower rate than the most pessimistic estimate, leading to a revised estimate of 2017-2021 before any traffic restrictions.

Feta implemented dehumidification of the west cable in 2008 and the east cable in 2009. Subsequent cable inspections 
indicated that the rate of corrosion of the cables had been reduced. However, the results are uncertain and no unconditional guarantee can be given about the potential future strength of the cables.

Investigations into replacing or augmenting the cables were also undertaken by Feta, but it was concluded that these works could not be undertaken without unacceptably high levels of disruption to traffic across the Forth. Closing the bridge to HGVs and potentially other types of vehicles would have a very serious impact on the economy of Scotland as a whole and Edinburgh and the Lothian and Fife Council areas in particular. These facts, together with other significant ongoing maintenance issues, led the Scottish government to conclude that the Forth Road Bridge could not be relied on to provide the main crossing for traffic across the Forth.

The replacement crossing, the Queensferry Crossing, safeguards this vital connection and also improves the reliability of journey times across the Forth by addressing issues that frequently affect the current Forth Road Bridge. These include its lack of hard shoulders to manage vehicle breakdowns and maintenance activities such as carriageway resurfacing, and lack of wind shielding, which results in closure for certain types of vehicles during high winds.

The existing road and rail bridges, and the Queensferry Crossing to the west (the left of the photo), are shown in Figure 1.

\section{Forth replacement crossing study}

Following Feta's initial cable investigations, in 2006 Transport Scotland commissioned a Forth replacement crossing study (Jacobs UK Ltd/Faber Maunsell Aecom, 2007) to determine the best solution. This used the Scottish transport appraisal guidance (Stag) methodology, which is an evidence-led, objective-based appraisal process.

Eight transport planning objectives were established at an early stage, based around capacity, accessibility, environment, maintainability, connectivity, reliability, increasing travel choices and sustainable development. A key objective was that traffic capacity should generally remain at 2006 levels and any replacement crossing should not result in a marked increase in cross-Forth traffic levels.

The sensitive location of the crossing necessitated an environmental review at an early stage to consider a number of local, national and internationally protected sites and features, including

- special protection areas (European designated sites) important habitats for rare and migratory birds

- Ramsar sites - wetlands of international importance

- special areas of conservation (European designated sites) with listed species of flora and fauna

- sites of special scientific interest - areas of national importance for wildlife or geology.

A total of 65 initial options including tunnels, bridges and barrages were sifted against the study objectives and appraised in relation to the Scottish government criteria of economy, environment, integration, safety and accessibility and social inclusion. This led to the assessment in more detail of options along five potential corridors, labelled as A to E, as shown in Figure 2.

Corridors A and B were sifted out at an early stage due to the longer route length and the significant new road connections

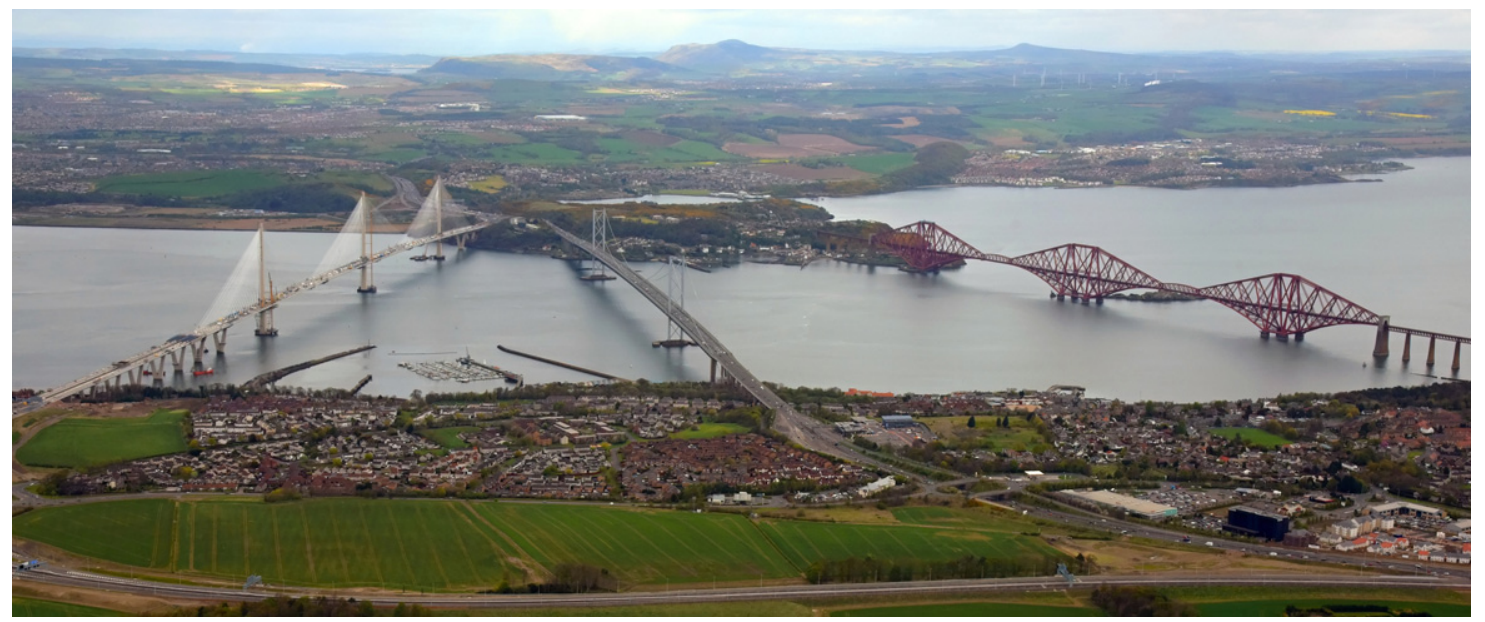

Figure 1. Existing and new Forth Bridges: 2017 Queensferry Crossing (left); 1964 Forth Road Bridge (middle); 1890 Forth Bridge (right) 


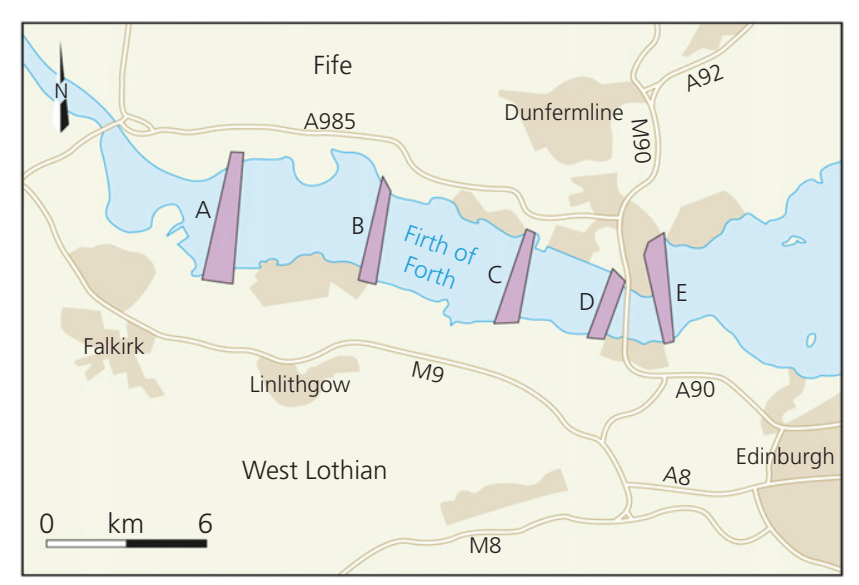

Figure 2. Five potential crossing corridors

required on the north side of the Forth. This left corridors $\mathrm{C}, \mathrm{D}$ and $\mathrm{E}$, which were deemed to perform well against the objectives. These were then taken forward for further detailed appraisal with bridge and tunnel options being considered for all three corridors.

Benchmarking against the Stag environment objectives and the study-specific planning objectives highlighted the critical issue to 'minimise the impact on people, the natural and cultural heritage of the Forth area' (Dudgeon, 2007: pp. 55-59).

The bridge proposals in corridors $\mathrm{C}$ and $\mathrm{E}$ did not perform well due to their proximity to the special protection areas within and adjacent to the Forth. In particular, both of these options were considered to have major adverse impacts on a European designated site, due to the likely loss of special protection area habitat. Therefore, they were unlikely to be permitted when viable alternatives existed that had less or no adverse impact. The bridge in corridor D was considered to avoid this impact.

Further appraisals were therefore undertaken on tunnels in all three corridors and a bridge in corridor D. There were two types of bridge options considered, both with $40 \mathrm{~m}$ wide decks. The first was a suspension bridge with a $1375 \mathrm{~m}$ main span and the second was a cable-stayed bridge with two main spans of $650 \mathrm{~m}$. Initially, bored tunnels were considered at these locations and further work was undertaken in 2007 to establish the feasibility of an immersed-tube tunnel (ITT) along corridor $\mathrm{C}$.

A strategic environmental assessment was undertaken on the Forth replacement crossing in 2007 (Ritchie and Walker, 2007). Additionally in 2007, a strategic-level appropriate assessment was undertaken because a new crossing had the potential to affect up to three European designated 'Natura 2000' sites (the Firth of Forth and Forth Islands special protection areas and the River Teith special area of conservation) and the Firth of Forth Ramsar site.

\subsection{Tunnel and bridge options}

Comparisons were made between the tunnel and bridge options in order to help determine the most appropriate option. These are summarised in Tables 1 and 2 .

In all scenarios analysed in the part 2 Stag appraisal, the monetised benefits were greater than the costs (Dudgeon, 2007). The corridor D bridge produced the most favourable results, with the lower cost of the cable-stayed variant giving the highest net present value and benefit-cost ratio.

The most favourable tunnel option in economic terms was that of corridor E. This option produced the highest level of monetised benefits, but at a significantly higher level of cost than the corridor D bridge. This resulted in an inferior net present value and benefit-cost ratio.

\subsection{Tunnel options}

The tunnel in corridor E was determined not to be worthy of further consideration because of environmental impacts, construction risks, the impact of drill and blast construction techniques, mine workings on the south side and high cost.

There was little to choose between the remaining tunnel options in corridors $\mathrm{C}$ and $\mathrm{D}$, since they had similar construction periods ( $7 \cdot 5$ years) and similar costs ( $£ 2 \cdot 2-2 \cdot 3$ billion). Neither would impact on the special protection areas and the overall environmental benefits of both were similar. Since pedestrians and cyclists would not be permitted into the tunnels for safety reasons, the tunnel options would not be able to provide the same functionality as a bridge crossing.

\subsection{Bridge options}

Of the two types of bridge structure, the cable-stayed bridge was found to have advantages over the suspension bridge, being the cheaper option and capable of being delivered around 6 months earlier (in a time frame of 5.5 years). The suspension bridge also required more complex foundations/ anchorages on the landfalls, which additionally invoked a risk from methane on the southern side of the Forth, whereas the use of a cable-stayed arrangement did not.

A modern cable-stayed bridge provided the unique situation at the Forth of three different types of bridge construction from three different centuries in close proximity - the cantilever structure of the 1890 Forth Bridge carrying rail, the 1964 longspan suspension Forth Road Bridge and the new Forth replacement crossing cable-stayed bridge (Figure 1). 
Table 1. Comparison of cost and construction time

\begin{tabular}{|lccc|}
\hline Crossing type & Construction time: years & Cost ratio to cheapest & Benefit-cost ratio \\
\hline ITT & $5 \cdot 5$ & $1 \cdot 4$ & $2 \cdot 91$ \\
Bored tunnel & $7 \cdot 5$ & $1 \cdot 5$ & $2 \cdot 23-2 \cdot 70$ \\
Suspension bridge & $6 \cdot 0$ & $1 \cdot 1$ & $3 \cdot 83$ \\
Cable-stayed bridge & $5 \cdot 5$ & $1 \cdot 0$ & $4 \cdot 31$
\end{tabular}

Table 2. Comparison of crossing types

\begin{tabular}{lclllll} 
Rating & $\begin{array}{c}\text { Impact on the environmentally } \\
\text { protected sites of the Forth }\end{array}$ & $\begin{array}{l}\text { Operating } \\
\text { restrictions }\end{array}$ & Operational risk & Cost & Cost risk & $\begin{array}{l}\text { Time to } \\
\text { construct }\end{array}$ \\
\hline Poor & ITT & Bored tunnel & Bored tunnel and ITT & Bored tunnel & Bored tunnel & Bored tunnel \\
OK & Bridge & ITT & Bored tunnel and ITT & ITT & ITT & Bridge and ITT \\
Good & Bored tunnel & Bridge & Bridge & Bridge & Bridge & Bridge and ITT \\
\hline
\end{tabular}

However, the bridge options were assessed to perform less well environmentally than the tunnel options in corridors $\mathrm{C}$ and D. Direct impacts on St Margaret's Marsh (a site of special scientific interest) on the north side of the estuary were likely and there could also be indirect disturbance to protected species within the special protection areas at both the Forth Islands and the Firth of Forth, which would impose seasonal constraints during construction. However, these constraints could be mitigated with nominal construction time and cost penalties.

The study concluded that a bridge in corridor D would be significantly cheaper than the tunnel options, could be delivered more quickly, had fewer risks associated with construction and demonstrated the best value for money.

\subsection{Recommended scheme}

A cable-stayed bridge in corridor $\mathrm{D}$, slightly west of the Forth Road Bridge, was recommended as the preferred scheme. This alignment makes use of Beamer Rock, a natural dolerite outcrop in the middle of the Forth, providing a suitable foundation for the central tower of the three-tower cablestayed bridge.

Following a comprehensive public consultation exercise in mid2007 and further consideration of the means to accommodate future travel demand across the Forth, it was determined that the replacement crossing should be 'multimodal' in nature and include provision for a future dedicated public transport corridor. This meant that the new bridge would be wider than previously envisaged, in excess of $50 \mathrm{~m}$.

Pedestrians and cyclists would also be accommodated on dedicated facilities located at the edges of the structure (see Figures 3 and 4). This recommendation was accepted and in December 2007 the Scottish government announced that 'the Forth Replacement Crossing should be a cable-stayed bridge with multimodal capacity on a route slightly to the west of the existing road bridge' (SP, 2007: col. 4552).

The estimated cost of the project was between $£ 3 \cdot 2$ billion and $£ 4 \cdot 2$ billion and it would be delivered by the end of 2016 .

\section{Scheme preparation and development}

\subsection{Selection of consultant}

In January 2008, Transport Scotland, by way of a competitive tendering exercise, procured the services of a Jacobs-Arup joint venture to assist with the management and delivery of the Forth replacement crossing project.

The scope of the commission included development and assessment of the project proposals, concept and specimen design of the bridge, preparation of an environmental statement, preparation of contract documents, assistance in the procurement and authorisation of the project and subsequent administration and monitoring of construction.

The project was managed by an integrated team of staff from Transport Scotland, Jacobs and Arup. The team was co-located in Transport Scotland's Glasgow office until mid2011 when the integrated team was relocated to the construction site in Rosyth.

\subsection{Initial scheme preparation}

Following the ministerial announcement at the end of 2007, the assumption was that the Forth replacement crossing was to provide for all road vehicles, pedestrians and cyclists. No future functional use of the existing road bridge was envisaged. The scheme was planned to incorporate two lanes with hard shoulders plus pedestrian walkways and cycleways in each direction. A multimodal corridor was to be provided on the new bridge and to connect with the adjacent network to cater 


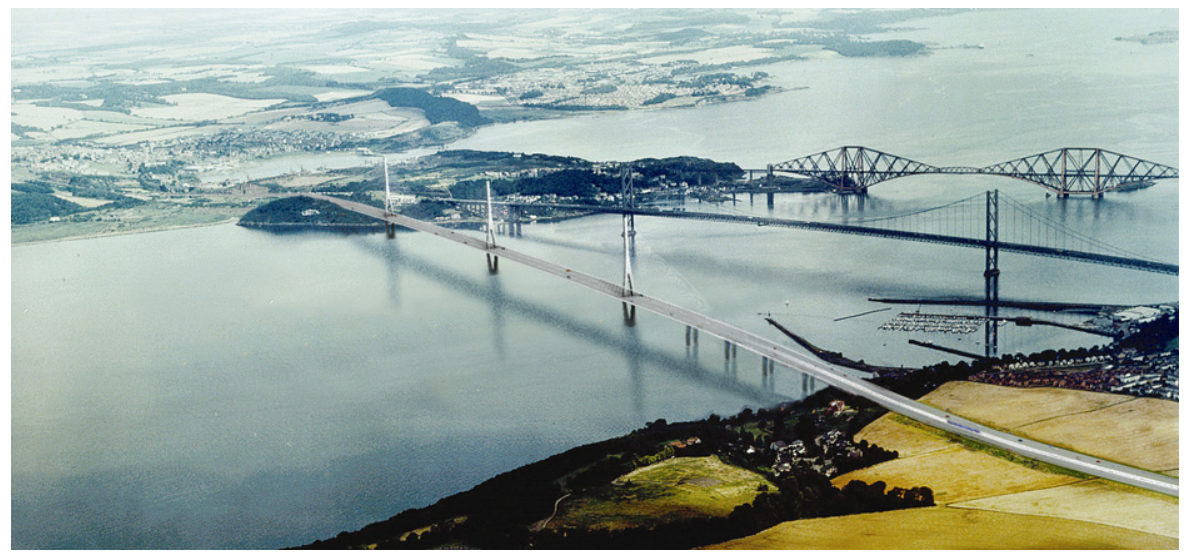

Figure 3. Artist's impression of the Forth replacement crossing including public transport corridor, 2007

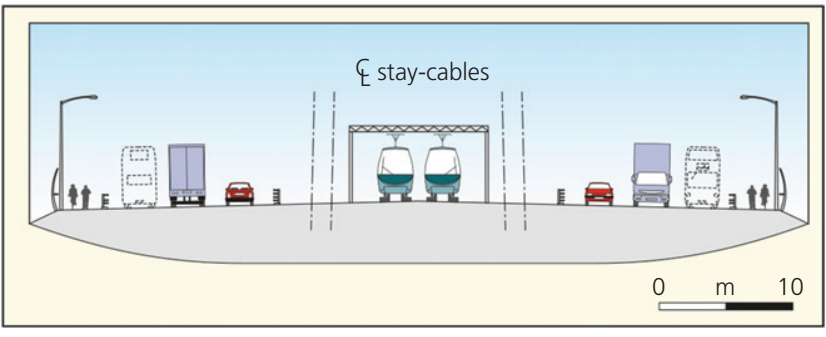

Figure 4. Proposed functional cross-section of $50 \mathrm{~m}$ wide multimodal bridge, with peak-hour bus operation on hard shoulder

for public transport needs, including the possibility of a light rapid transit system or trams in the future.

Motorway-standard road connections were to be provided, principally to join the A90/M90 to the north of the Forth and to the M9 and A90 in the south, for a total approximate length of $22 \mathrm{~km}$. The scheme preparation was therefore progressed on that basis, as shown in Figure 4.

\subsection{Future use of the Forth Road Bridge}

In early 2008, Feta reported on its second cable investigation, which gave an improved prognosis for the rate of cable deterioration. This, together with the removal of general traffic from the Forth Road Bridge (which constitutes some 15\% of the loading in the cables), provided some hope that a functional use for the existing road bridge might be possible. Previously, the view given as part of the Forth replacement crossing study was that the existing bridge would not be suitable for future light rail use. However, it was felt within the Forth replacement crossing team that this finding should be challenged, particularly in relation to perceived problems with rotations at expansion joints.
A feasibility study was therefore carried out to evaluate the suitability of the suspension bridge to carry a future light rail system. This study demonstrated that the Forth Road Bridge could provide the desired dedicated public transport corridor. Additionally, if the Forth Road Bridge was to be retained, it could also continue to accommodate pedestrian and cyclist facilities. The Forth replacement crossing could therefore be slimmed down significantly (to around $40 \mathrm{~m}$ width (Figure 5)), despite the decision to adopt widened hard shoulders to provide increased operational flexibility.

\subsection{New bridge design}

Taking the above Forth Road Bridge assumptions into consideration, the design of the new bridge was progressed. A wide range of design issues was addressed, which are discussed in more detail in other papers in this issue. These design issues included the following.

- Stabilisation of the central tower. With a three-tower cable-stayed bridge exhibiting much larger deflections than those of a two-tower bridge, a unique solution incorporating a length of crossed cables at mid-span was

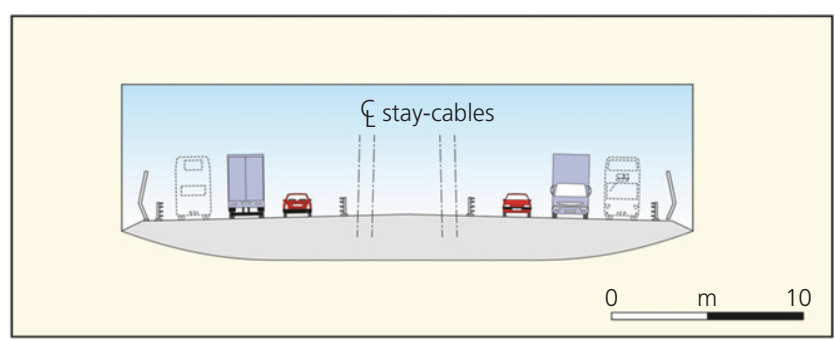

Figure 5. Final functional cross-section of $40 \mathrm{~m}$ wide bridge with periodic bus operation on hard shoulder 
developed to increase the overall stiffness of the structure, enabling the adoption of a slender deck and towers.

This major innovation substantially reduced the cost of the bridge and its foundations.

- Navigation clearances. The provision of at least equivalent clearance to that provided by the Forth Road Bridge and Forth Rail Bridge was required.

- Wind shielding. Wind shields were required to provide almost guaranteed ability to cross in high winds and to maintain views by specifying transparent wind shields.

- Ship impact. Extensive investigations were undertaken into the likely types, weights, speeds and direction of vessels using the Forth to consider the risk and potential outcome of a vessel hitting a tower or pier. The 'as low as is reasonably practical' principle was adopted to best manage the engineering and cost implications; this resulted in increased protection to the south tower and the adjacent pier due to their locations on the outside bend of the main shipping channel. These design criteria were specified to the tenderers.

- Tower foundations. To inform the foundation design, extensive ground and marine investigations were undertaken, split between three contracts (the last one undertaken with the tenderers to accommodate any additional requirements they had to suit their design) to ensure the availability of comprehensive information for foundation and temporary works design and construction. Both caissons and piles were considered to be acceptable solutions, with the successful contractor being best placed to choose.

Deck type/shape. After consideration of various arrangements (including a ladder-deck, truss and Vierendeel), a trapezoidal-shaped deck (aerodynamic box with smooth surfaces) was preferred to minimise future maintenance, assist with wind loading and improve aesthetics. However, the choice of materials (orthotropic or composite) was left open for the contractor, although specimen designs were provided to the tenderers to assist them during the early stages of the tender process.

Environmental constraints on construction. These included proximity to the special protection areas, setting limiting criteria for construction noise and vibration and preventing interference with cetaceans and other marine life.

- Aesthetics. Consideration of the new bridge's setting and its close proximity to the Forth Road Bridge and Forth Bridge greatly influenced the design, particularly in respect of the towers. Simple, slender monopoles were adopted to minimise any visual conflict and this met with the approval of Architecture and Design Scotland.

Addressing these issues culminated in a robust and aesthetically pleasing specimen design that the tenderers could use to develop into a detailed design, within the geometric constraints specified. Figure 6 shows an artist's impression of the intended bridge.

In conjunction with the reduction in the width of the bridge, the above innovations and value-engineering initiatives greatly simplified the design and construction of the bridge and its consequent cost.

\subsection{Road connections and ITS}

In view of the high cost estimate, it was recognised that the network connections would also be subject to a thorough value-engineering exercise, making best use of existing infrastructure where possible.

The incorporation of an ITS was first suggested during the Forth replacement crossing study. Use of variable mandatory speed limits combined with variable message signs and other features such as closed-circuit television coverage of the roads concerned had proven to provide operational benefits on roads such as the M42 around Birmingham. As congestion builds, the variable mandatory speed limits displayed on overhead gantries steadily reduce speeds, smoothing the traffic flow and thus reducing congestion and emissions. The system has also been shown to improve safety as it helps to avoid stop-start conditions, in particular rear-end shunts into stationary traffic. Use of this technology was deemed to be a pragmatic way of managing the relatively heavy traffic flows along the project corridor and helping to minimise new road construction.

South of the Forth, six principal options were considered to connect the new bridge to the M9 and A90 (see Figure 7). All options were assessed in relation to a number of factors, including cost, environmental impact, connectivity/traffic

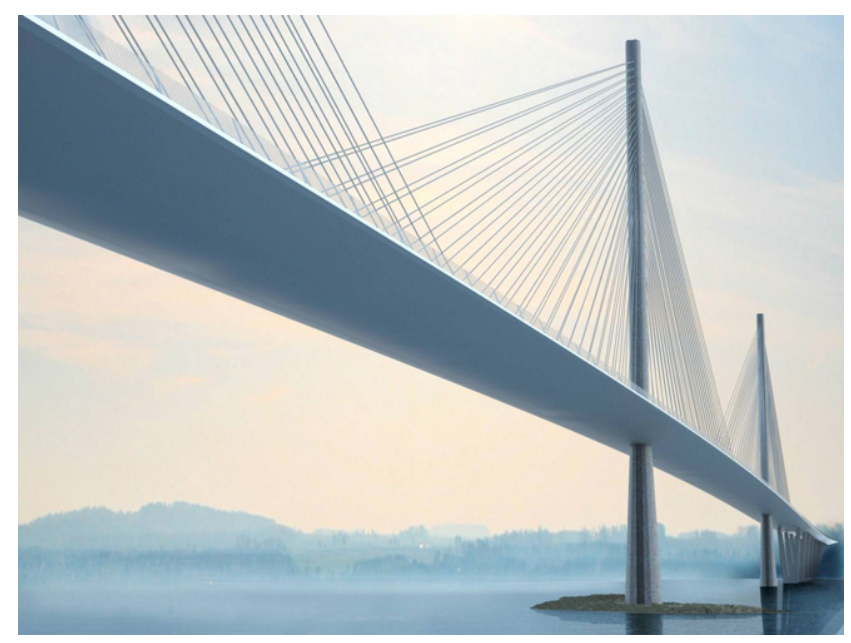

Figure 6. Artist's impression of Queensferry Crossing, 2010 


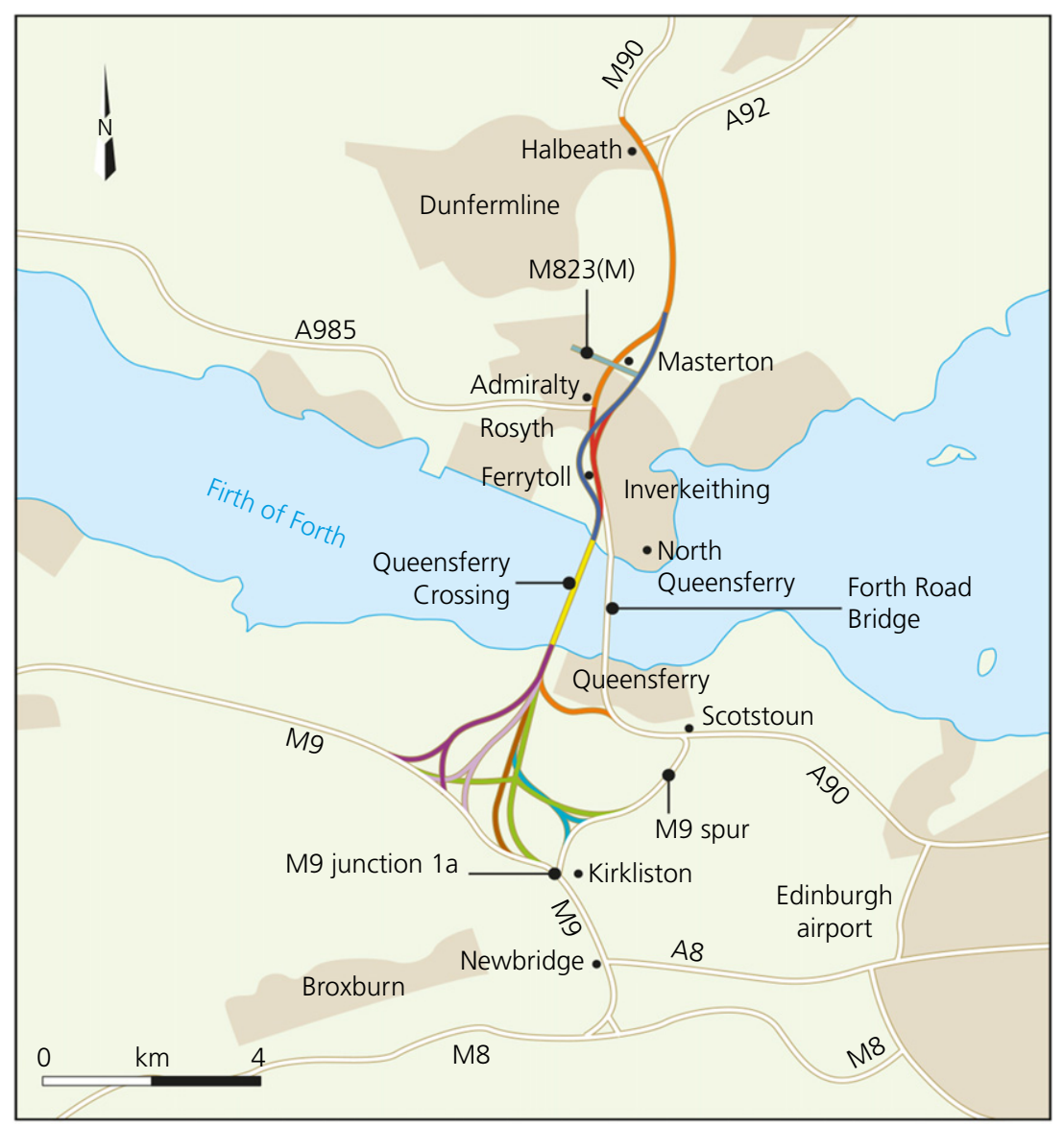

Figure 7. Road connection options

routing, design standards (in particular junction spacing) and ground conditions.

The optimum arrangement was to construct a new length of motorway-standard road from the new bridge around the west and south of Queensferry to connect to the A90/M9 spur junction at Scotstoun. A junction with the local network would be provided on the A904. The connection to the M9 would then utilise the recently constructed M9 spur in preference to the much more expensive new direct alignments involving large new motorway junctions. Better connectivity to the M9 west would be provided by upgrading M9 junction 1a to an all-ways junction and capacity enhancements would be provided by road widening of the existing M9 towards the Newbridge junction. This arrangement was the least costly (in particular by incorporating the M9 spur) and had the lowest environmental impact.

North of the Forth, three main options (see Figure 7) were considered, broadly online, offline and a mix of online/offline. Junction layouts and their spacing, road alignment and ground conditions were principal considerations. Initially it was envisaged that the road should be a three-lane motorway extending up to the M90/A92 interchange at Halbeath.

However, utilising an ITS to make best use of the existing road space meant that a more considered approach could be adopted. Thus, new road construction was to be provided from the new bridge up to junction 1 of the M90 at Admiralty with a remodelled junction at Ferrytoll to maintain connectivity to the local road network in and around Rosyth, Inverkeithing and North Queensferry.

These considerations led to a significant reduction in the extent of the road network connections. The incorporation of the ITS, across a $22 \mathrm{~km}$ length from Halbeath to Newbridge, was to be the first application of this technology in Scotland.

\subsection{Managed crossing strategy}

All of the previously described measures formed the 'managed crossing strategy', with reuse of the existing bridge, the adoption of a crossed-cable configuration and a reduced extent of new 
road construction being key elements in revising the scope of the project. These changes resulted in a much reduced cost estimate of between $£ 1.7$ billion and $£ 2.3$ billion. The strategy was announced by the Scottish government in December 2009 and formed the basis for progressing the project.

\subsection{Public transport}

Further enhancements to the proposed scheme were developed with the key aims of ensuring journey time reliability and enhancing public transport services and facilities as far as possible (Figure 8). These included

- bus hard-shoulder running in two southbound locations (M90 Halbeath to Admiralty and M9 spur to Newbridge) - the first such schemes in Scotland

- dedicated public transport links to and from the Forth Road Bridge to the A90 with the eastbound link forming a direct connection to the existing A90 Edinburgh-bound bus lane

an additional 1000-space park and ride facility at Halbeath to be provided by Fife Council

- use of the new bridge's hard shoulders by public transport when wind prevents them using the Forth Road Bridge.

\section{Parliamentary process}

Transport Scotland's road-based projects are normally authorised by way of the Roads (Scotland) Act 1984. However, because of the wide range of functions the project was to provide, including the provision for possible light rail or trams in the future, it was felt that the scope of this act would not be sufficient and its use could give rise to an increased risk of legal challenge and delay. It was therefore determined that primary legislation, by way of a parliamentary bill, was required.

Scottish ministers introduced the Forth Crossing bill to the Scottish parliament on 16 November 2009, outlining proposals for the Forth replacement crossing (SP, 2009). Transport Scotland produced a full suite of accompanying documents to support the bill and staged public information exhibitions to make this documentation available for public inspection. These documents, as well as all previously published material were additionally placed on the Transport Scotland website. This was the first hybrid bill of its type taken forward in Scotland.

As part of the parliamentary process, there was a $60 \mathrm{~d}$ objection period during which objections to the bill could be made to the Scottish parliament. In total, 90 objections were received.

Officials from the Forth replacement crossing project team gave evidence at various parliamentary bill committee sessions and, in particular, during the sessions at which the objections were considered in detail in front of an independent assessor. In consideration of the objections, a number of commitments were identified and added to the employer's requirements for the construction phase.

The bill process ran in parallel with the procurement process and culminated in a final parliamentary debate on 15 December 2010, which confirmed acceptance of the scheme almost unanimously.

On 20 January 2011, Royal Assent was granted and the Forth Crossing bill became the Forth Crossing Act 2011.

\section{Procurement}

\subsection{Design-and-build contract}

Following a review of interface management and a desire to provide opportunities to a range of contractors, the project was divided into three contracts (see Figure 9). These were the 'principal contract', which included the main crossing and connecting roads, and two smaller contracts - 'Fife ITS' for the ITS in Fife to the north of the Forth and 'M9 junction 1a' for associated road-improvement works in and around that junction to the south.

Price surety was one of the key aims of the project and therefore it was decided to adopt the design-and-build type of contract, albeit with a high level of scope definition and supporting information to assist the tenderers. Various funding mechanisms were investigated but, in view of the difficulty in obtaining private finance given the economic crisis prevailing in 2009, it was decided that the project would be funded directly by the Scottish government.

In view of the large size of the principal contract and the likelihood of attracting international consortia to bid, a contract form based on the standard conditions for turnkey projects published by the International Federation of Consulting Engineers (Fidic, 1999) was adopted. The price was a lumpsum basis with $90 \%$ of the inflation risk over the project period being taken by the client and monthly payments made for progress measured against a schedule of milestones. A simplified form of contract was adopted for the two smaller contracts.

Two participants were shortlisted for the tender competition for the principal contract

- Forthspan - a joint venture of Morgan Sindall, BAM Nuttall, Balfour Beatty and Vinci (later replaced by MT Hojgaard)

- Forth Crossing Bridge Constructors (FCBC) - a joint venture of Hochtief, American Bridge, Dragados and Morrison Construction. 


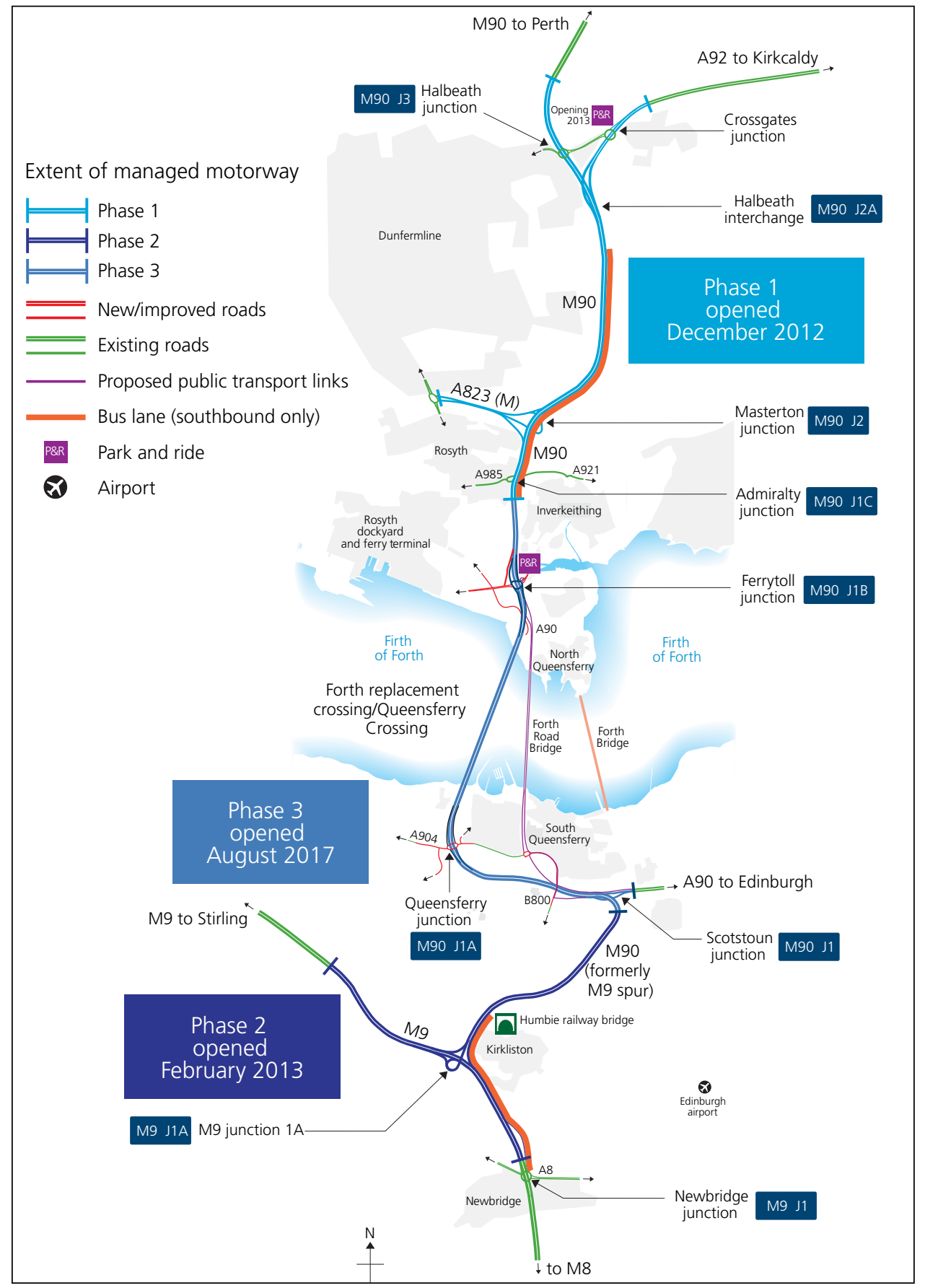

Figure 8. Forth replacement crossing project: bridge location and road layout including public transport links

\subsection{Dialogue period}

The competition for the principal contract was undertaken in parallel with the progression of a parliamentary bill. It would normally be desirable to have the legislative powers required in place prior to a tender competition, but the parallel process was necessary due to the time constraints for project delivery.
To provide some comfort to the tendering parties and to encourage them to submit compliant bids, a participation agreement was signed on the basis that

- half of the tender costs up to a value of $£ 5$ million would be paid to the unsuccessful tenderer 


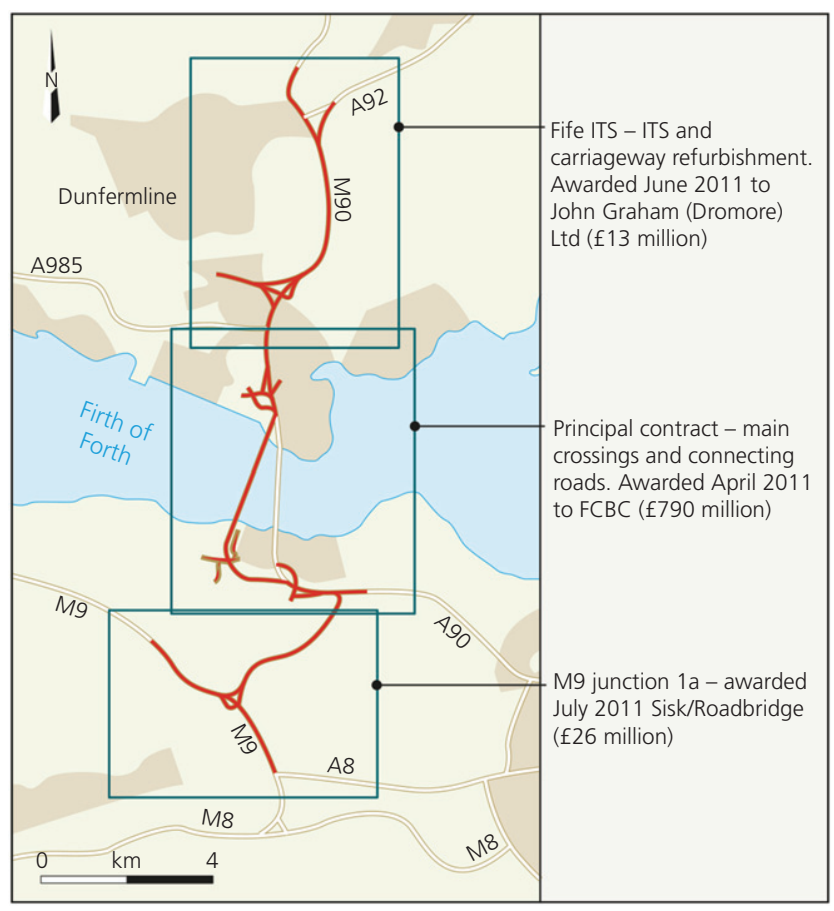

Figure 9. Forth replacement crossing contracts

- full tender costs up to a value of $£ 10$ million would be paid to both tenderers should Scottish ministers decide not to continue with the project.

In December 2009, a set of contract documents, including the employer's requirements and definition drawings were issued to the participants. The definition drawings indicated the minimum requirements that must be followed in terms of the overall form and geometry of the bridge. Also, specimen designs were made available to give examples of how the bridge, roads and associated infrastructure may be designed to satisfy the specified requirements. Throughout 2010, participating consortia prepared their outline proposals for the project and additional ground and marine investigations were undertaken to help inform these.

A formal dialogue process between participants and the Forth replacement crossing team took place throughout the tender period to ensure that participants thoroughly understood Transport Scotland's requirements and to provide evidence to the Forth replacement crossing team that the participants' proposals were capable of being developed into acceptable designs.

\subsection{Contract awards}

Following the granting of Royal Assent in early 2011, the preferred bidder was announced to be FCBC and the contract

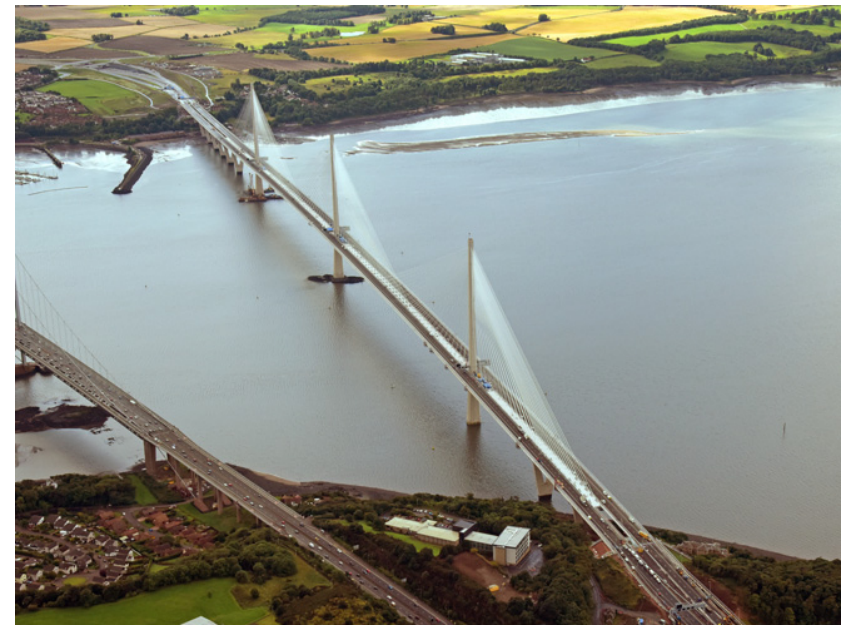

Figure 10. Completed Queensferry Crossing

Table 3. Key project stages

\begin{tabular}{|c|c|}
\hline Stage & Date \\
\hline Forth replacement crossing study & August 2006-June 2007 \\
\hline Public exhibition & August 2008 \\
\hline $\begin{array}{l}\text { Scottish government confirms bridge } \\
\text { crossing }\end{array}$ & December 2007 \\
\hline Consultant Jacobs-Arup appointed & January 2008 \\
\hline Environmental surveys commence & February 2008 \\
\hline Land searches & February 2008 \\
\hline Traffic surveys begin & March 2008 \\
\hline Marine ground investigations & May-August 2008 \\
\hline Topographical surveys & March-August 2008 \\
\hline Land-based ground investigations & March-August 2008 \\
\hline $\begin{array}{l}\text { Scottish government confirms scheme } \\
\text { details }\end{array}$ & December 2008 \\
\hline Public exhibitions & January 2009 \\
\hline $\begin{array}{l}\text { Environmental impact assessment } \\
\text { concluded }\end{array}$ & Summer 2009 \\
\hline $\begin{array}{l}\text { Parliamentary bill introduced and } \\
\text { statutory consultation }\end{array}$ & November 2009 \\
\hline Competitive dialogue process begins & December 2009 \\
\hline Royal assent - Forth Crossing Act 2011 & January 2011 \\
\hline $\begin{array}{l}\text { Construction contract (principal } \\
\text { contract) signed }\end{array}$ & April 2011 \\
\hline Construction begins (all contracts) & Summer 2011 \\
\hline Queensferry Crossing opens to traffic & August 2017 \\
\hline
\end{tabular}

for $£ 790$ million (a significant saving on the estimate of between $£ 900$ million and $£ 1.2$ billion) was signed on 18 April 2011.

The smaller contracts were procured during 2010/2011 and these also offered significant savings on the pre-construction estimates. 
Going into the construction phase of the project, the overall estimated outturn cost was markedly reduced to the range of $£ 1.45$ billion to $£ 1.6$ billion.

\section{Summary}

The Forth replacement crossing project was, by necessity, developed rapidly from mid-2006. By January 2011, a highdefinition project specification had been completed, necessary legal powers to construct the crossing had been granted by way of the successful passage of the Forth Crossing bill through the Scottish parliament and, by summer 2011, all the construction contracts had been awarded.

The crossing opened to traffic in August 2017 (Figure 10). The official opening by Her Majesty Queen Elizabeth II was on 4 September 2017 , exactly 53 years to the day after she opened the Forth Road Bridge and only 10 weeks after the contracted opening date agreed in 2011 and at an outturn cost of $£ 1.34$ billion. The key dates for the project are provided in Table 3. Transport Scotland (2019) has a website which provides extensive background information to the project.

\section{REFERENCES}

Anderson JK, Hamilton JAK, Henderson W et al. (1965) Forth Road Bridge: history and finance. Proceedings of the Institution of Civil Engineers 32(3): 321-331, https://doi.org/10.1680/ iicep.1965.22317.

Colford BR (2008) Forth road bridge - maintenance and remedial works. Proceedings of the Institution of Civil Engineers - Bridge Engineering 161(3): 125-132, https://doi.org/10.1680/bren.2008. 161.3 .125 .
Colford B (2011) Forth Road Bridge - main cables and anchorages. Proceedings of the IABSE-IASS Symposium: Taller, Longer, Lighter, London, UK, IABSE, Zurich, Switzerland.

Dudgeon I (2007) Forth Replacement Crossing Study: Report 5 - Final Report. Jacobs, Glasgow, UK. See http://www.transport.gov. scot/road/forth-replacement-crossing/forth-replacement-crossingstudy-2007 (accessed 21/04/2016).

Fidic (International Federation of Consulting Engineers) (1999) Conditions of Contract for EPC/Turnkey Projects. Fidic, Geneva, Switzerland.

Forth Crossing Act 2011. Asp 2. Her Majesty's Stationery Office, Edinburgh, UK.

Jacobs UK Ltd and Faber Maunsell/Aecom (2007) Forth Replacement Crossing Study: Volumes 1 to 5. See https://www.transport.gov. scot/projects/forth-replacement-crossing/document-library/forthreplacement-crossing-study-2007/ (accessed 02/04/2019).

Mackay S (1993) Forth Bridge - A Picture History. Her Majesty's Stationery Office, London, UK.

Ritchie D and Walker E (2007) Forth Replacement Crossing Study: Strategic Environmental Assessment: Environmental Report. Jacobs, Glasgow, UK. See http://www.transport.gov.scot/road/forthreplacement-crossing/forthreplacement-crossing-study-2007 (accessed 21/04/2016).

Roads (Scotland) Act 1984. Chapter 54. Her Majesty's Stationery Office, London, UK.

SP (Scottish Parliament) (2007) Meeting of the parliament Wednesday 19 December 2007. Official Report, cols 4548-4564. See http://www.parliament.scot/parliamentarybusiness/report.aspx? $r=4763 \& i=39429 \& c=908683 \& s=$ Forth $\% 2520$ Replacement $\%$ 2520Crossing (accessed 08/06/2016).

SP (2009) Forth Crossing Bill. SP, Edinburgh, UK. See http:// www.parliament.scot/parliamentarybusiness/Bills/22080.aspx (accessed 08/06/2016).

Transport Scotland (2019) Forth Replacement Crossing. Transport Scotland, Glasgow, UK. See https://www.transport.gov.scot/ projects/forth-replacement-crossing/ (accessed 02/04/2019).

\section{How can you contribute?}

To discuss this paper, please email up to 500 words to the editor at journals@ice.org.uk. Your contribution will be forwarded to the author(s) for a reply and, if considered appropriate by the editorial board, it will be published as discussion in a future issue of the journal.

Proceedings journals rely entirely on contributions from the civil engineering profession (and allied disciplines).

Information about how to submit your paper online is available at www.icevirtuallibrary.com/page/authors, where you will also find detailed author guidelines. 